\title{
Analysis on two wheeler chassis frame of e-bike subjected to static and impact loads
}

Naresh Kumar KONADA, Koka Naga Sai SUMAN

DOI: $10.30464 / j m e e .2020 .4 .1 .15$

Cite this article as:

Konada N. K., Suman K. N. S. Analysis on two wheeler chassis frame of e-bike subjected to static and impact loads. Journal of Mechanical and Energy Engineering, Vol. 4(44), No. 1, 2020, pp. 15-26.

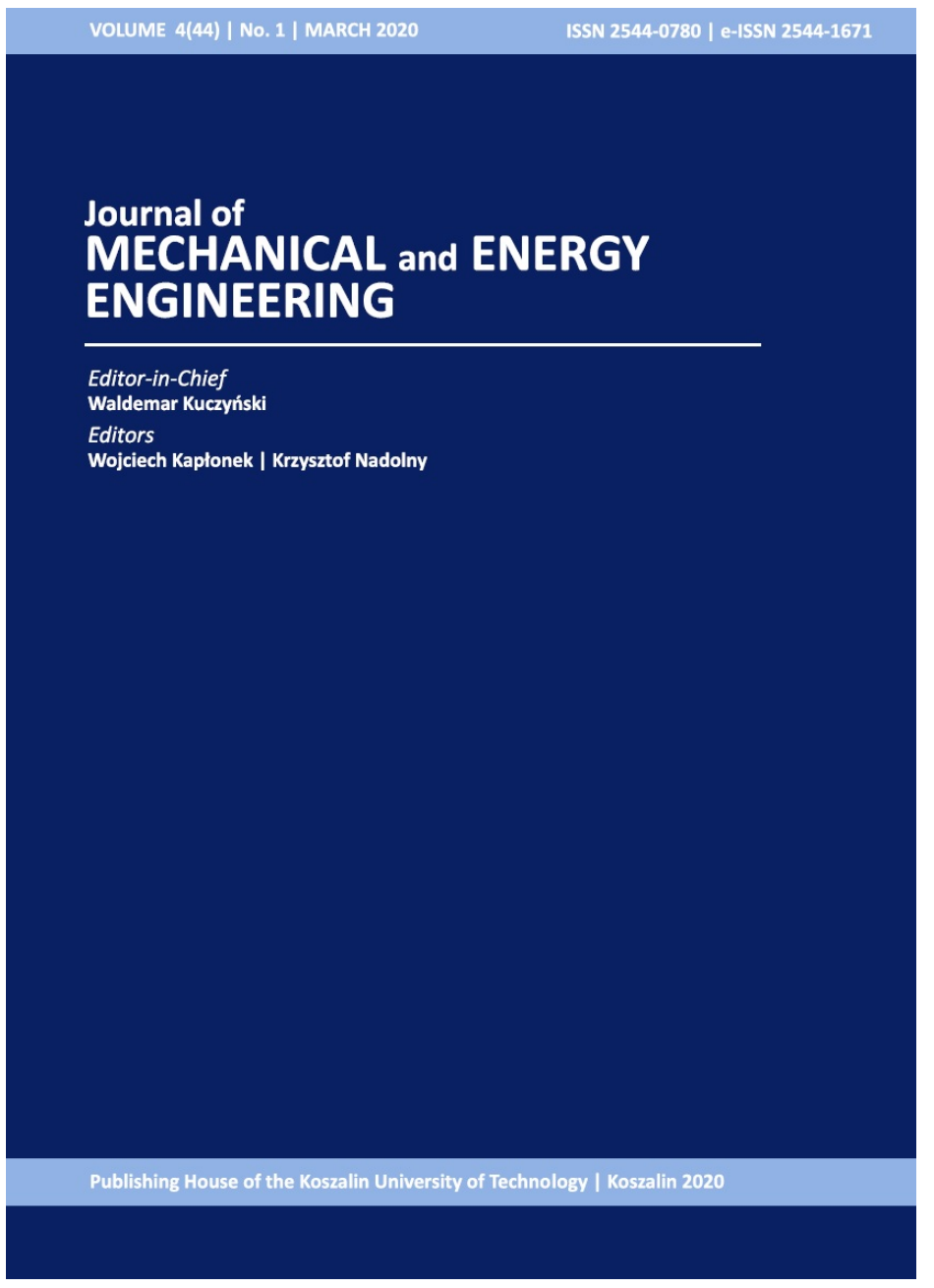

Journal of Mechanical and Energy Engineering

Website: jmee.tu.koszalin.pl

ISSN (Print): 2544-0780

ISSN (Online): 2544-1671

Volume: 4(44)

Number: 1

Year: 2020

Pages: 15-26

Article Info:

Received 2 April 2020

Accepted 9 April 2020

\section{Open Access}

This article is distributed under the terms of the Creative Commons Attribution 4.0 (CC BY 4.0) International License (http://creativecommons.org/licenses/by/4.0/), which permits unrestricted use, distribution, and reproduction in any medium, provided you give appropriate credit to the original author(s) and the source, provide a link to the Creative Commons license, and indicate if changes were made. 


\title{
ANALYSIS ON TWO WHEELER CHASSIS FRAME OF E-BIKE SUBJECTED TO STATIC AND IMPACT LOADS
}

\author{
Naresh Kumar KONADA ${ }^{1 *}$, Koka Naga Sai SUMAN ${ }^{2}$ \\ $1^{*}$ Asst Professor, Mechanical department, Anits Engineering College, Andhra Pradesh, India, \\ e-mail: nareshkonada@gmail.com \\ ${ }^{2}$ Associate Professor, Department of mechanical Engineering, Andhra University Andhra Pradesh, India, \\ e-mail: sumankoka@yahoo.com
}

(Received 2 April 2020, Accepted 9 April 2020)

\begin{abstract}
The future of automotive industry is to design and develop electrical vehicles to control the emissions released from gaseous fuels and not to release any harmful gases in to atmosphere. In this work, an attempt was made to analyze the behavior of two wheeler E- bike with alternative materials of frame such as Aluminum alloy (Al-A), Titanium alloy (Ti-A), Grey cast iron (G-CI), Carbon fiber epoxy (CF-E), and Structural steel (ST-S) and compared with AISI-1020 material. The frame of Yamaha R15 is initially modeled by using solid work and imported to Ansys. Static analysis was performed by applying a load of $1500 \mathrm{~N}$ on the frame and Impact analysis was performed by applying velocity of $27.7 \mathrm{~m} / \mathrm{s}$ along $X$ direction. The values of equivalent von Mises stress and total deformation for all the materials are observed. After performing static analysis, it was observed that, CF- Epoxy material exhibited higher value of Equivalent von Mises stress $(7.659 * 107 \mathrm{~Pa})$ and lower total deformation of $\left(0.304 \times 10^{-6} \mathrm{~mm}\right)$ compared to remaining materials. Based on impact analysis, it was observed that, CF-E exhibited better von Mises stress of (3994.9 MPa) closer to AISI 1020 and structural steel materials and total deformation is observed to be lower value $(0.1106 \mathrm{~mm})$ compared to remaining materials.
\end{abstract}

Keywords: Two wheeler chassis frame, Static and Impact analysis

\section{INTRODUCTION}

Automotive sector is considered as the main important sector to increase the economical growth of any country. The advancement in the technology enables the automotive industry to develop new design vehicles to meet stringent requirements of customers such as effective braking performance, safety, low cost and aesthetic appearance. The present trend in the automotive sector is to design and develop electrical vehicles to give same performance like petrol and diesel vehicles. Therefore, many industries are trying to design new type of electrical vehicles to meet with the present challenges such as zero emissions vehicle. In this context, more capacity batteries are being introduced to give better performance and improve mileage capacity of the vehicle. Few peoples are doing their research to incorporate graphite and other carbon based materials to store the energy for longer time and improve the performance of the vehicle. There is only limited research done on the analysis of electrical vehicles.

Y. Champoux, P. Vittecoq, P. Maltais et al 2004 optimized their choice of geometry and tube thickness of a bike frame for a modern design based on a finiteelement model. They presented new measurement techniques and an overview of the different approaches. The loads carried by off-road bikes provides crucial information to bike frame manufacturers, allowing them to develop and propose new and optimized versions of their product [1]. Michael Kaiser, Norbert Himmel et al 2005 gives an overview of the requirements for road and racing bike chassis using finite element analysis .In this work, he influence of the lay-up configuration on the frame stiffness is studied .The capability of CFRP (Carbon fiber reinforced plastic) was impressively 
demonstrated in the Canyon Flo which is one of the lightest and stiffest racing bike chassis worldwide today with an STW value of more than $100 \mathrm{Nm} /(\mathrm{O} \mathrm{kg})$ which is almost $40 \%$ higher compared to the best $\mathrm{Al}$ frame and a world-class record could be achieved through this study. It was also observed that, in case of high-end racing bike chassis sector, it can be expected that $\mathrm{Al}$ material can be substituted by CFRP [2].

Vignesh, Arumugam et al 2019 implemented the technology of E-bikes and performed the analysis of static simulations and torsional analysis for sudden impacts. In the present study, optimum design for an electric bike was modeled and analyzed for stress and failure rate for commercial purpose. The material used is of AISI3410 standard. The analysis comprised of static simulations and torsional analysis for sudden impacts of all the components in the frame. It was concluded AISI3410 material exhibited good results against static and impact loads acting on the frame [3]. Maulik Lohia et al 2017 minimizes the effect of vibrations in two wheeler chassis. The dynamic characteristics of the two wheeler chassis such as natural frequency and mode shape are determined using FEA. Author analyzed double cradle frame under rider weight case and engine weight case and compared both existing and modified double cradle frame in static structural analysis by using Solid Work 2015 simulation module. The main role of this research is to improve strength of chassis with respect to stability and comparison result of both existing and modified chassis [4]. Sergio Corbera Caraballo et al 2019 proposed an integrated methodology to support early stage design decision making for motorcycle rear suspensions. The proposed framework coupled with the NSGA-II algorithm is responsible for exploring and managing the optimal functional design. The workflow has been structured to follow the design actions in an automatic manner [5]. Balaguru $\mathrm{S}$ et al 2019 discussed the stress and deformation developed in chassis during the different load cases and identifying the failure modes by the modal analysis. It starts from the benchmark study of different scooter frames and circle cross section is preferred because of its easiness of manufacturing, even load distribution for different load cases and some other geometrical reasons. After performing structural and modal analysis of frame under the various load considerations using ANSYS, concluded that, frame design modifications are required to with stand loading conditions and necessary frame materials should be selected to decrease the chances of failures under critical loads and improve the damping behavior of the frame [6]. Kiran L et al proposed hybrid composite materials light commercial vehicle chassis. In this study authors analyzed the behavior of TATA ace chassis with three different alternative materials steel, aluminum and carbon fiber. It was observed from static analysis results that, design change of fish bone type with carbon fiber material exhibits better results compared to remaining materials [7]. Jeya pandiarajan $\mathrm{P}$ et al, conducted a study on design and analysis of chassis for an electric motor cycle. Author conducted swing arm analysis with three materials AISI 1020, AISI4340 and Aluminium 6063. It was observed from results that, AISI4340 material exhibits lower value of deformation $0.5 \mathrm{~mm}$ and Von Mises stress $1.734 \times 108 \mathrm{~Pa}$ compared to remaining materials [8]. Balaguru $\mathrm{S}$ analyzed scooter frame for design change and observed elliptical cross section design change exhibits better results [9].

Based on the various research works performed in the area of E-bikes, it was observed that, selection of materials plays a vital role to with stand loads acting on the chassis of automobile. Proper geometry of the frame with suitable stress reducers by providing fillets and removing unwanted materials will have the highest capability to with stand the load acting on the frame. This will also have the greater capability to absorb the vibrations generated in the vehicle and maintain the amplitude of frequency in the acceptable range. Hence, materials properties of the chassis frame plays a vital role to with stand the loads acting on it and produce lower deformations against various types of loads acting on it such as (static, dynamic and impact loads). In this work, the behavior of two wheeler electrical bike is analyzed for static and impact loads by changing various material properties of the frame. The best material which exhibits lower value of deformation and higher value of von Mises stress is considered for fabrication

\section{MATERIALS AND METHODS}

The material selection of an automobile plays a vital role for giving strength to the automobile. The load with standing capability primarily depends on the selection of materials. Steels are generally used in the automobile for sustaining low loads acting on the automobile. Many times, high alloy steels are used in automotive industry for manufacturing many components subjected to complex loads such as shaft, coupling, chassis etc. to sustain heavy loads acting on the automobile. Now a day's composite materials are widely used in automobiles to produce light weight, corrosion resistant and also for giving aesthetic appearance. In this study different materials are considered for analyzing the behavior of frame of two wheeler electrical bike against static and impact loads. The behavior of standard existing material of frame such as AISI 1020 is compared with remaining materials (G-CI, ST-S, CF-E, Ti-Al, and Al-Al).The mechanical properties of all the materials are given below. Table 1 and Table 2 give chemical composition and mechanical properties of AISI 1020 steel material. 
Tab. 1. Material composition of AISI 1020 steel

\begin{tabular}{ll}
\hline Element & Weight \% \\
\hline $\mathrm{C}$ & $0.18-0.23$ \\
\hline $\mathrm{Mn}$ & $0.30-0.60$ \\
\hline $\mathrm{P}$ & 0.04 \\
\hline $\mathrm{S}$ & 0.05 \\
\hline
\end{tabular}

The standard materials which are being used for various mechanical components like GCI, ST-S and Ti-A, Al-A, AISI1020 mechanical properties are directly available in the data base of Ansys Work bench .Remaining mechanical properties of CF-E which is a new composite material was entered manually by indicating all the properties of high grade carbon fiber composite.

Table 3 represents mechanical properties of Al-A, Table 4 to Table 7 represents mechanical properties of remaining materials considered in this study.

Tab. 2. Mechanical Properties of AISI 1020 material

\begin{tabular}{ll}
\hline Properties & Conditions \\
\hline Density $\left(\mathrm{kg} / \mathrm{m}^{3}\right)$ & 7870 \\
\hline Poisson's ratio & 0.29 \\
\hline Elastic Modulus $(\mathrm{Pa})$ & $2 \times 10^{11}$ \\
\hline Ultimate Tensile strength $(\mathrm{Pa})$ & $3.10 \times 10^{8}$ \\
\hline Tensile Yield Strength $(\mathrm{Pa})$ & $2.95 \times 10^{8}$ \\
\hline Compressive Yield Strength $(\mathrm{Pa})$ & $3.95 \times 10^{8}$ \\
\hline Bulk modulus $(\mathrm{Pa})$ & $1.58 \times 10^{11}$ \\
\hline Shear Modulus $(\mathrm{Pa})$ & $7.75 \times 10^{10}$ \\
\hline Coefficient of thermal expansion $\left(10-5 /{ }^{\circ} \mathrm{C}\right)$ & 1.19 \\
\hline Reference Temperature $\left(0^{\circ} \mathrm{C}\right)$ & 20 \\
\hline
\end{tabular}

Tab. 3. Mechanical Properties of Aluminium alloy

\begin{tabular}{ll}
\hline Properties & Conditions \\
\hline Density $\left(\mathrm{kg} / \mathrm{m}^{3}\right)$ & 2770 \\
\hline Poisson's ratio & 0.33 \\
\hline Elastic Modulus $(\mathrm{Pa})$ & $7.10 \times 10^{10}$ \\
\hline Ultimate Tensile strength $(\mathrm{Pa})$ & $3.10 \times 10^{8}$ \\
\hline Tensile Yield Strength $(\mathrm{Pa})$ & $2.80 \times 10^{8}$ \\
\hline Compressive Yield Strength $(\mathrm{Pa})$ & $2.80 \times 10^{8}$ \\
\hline Bulk modulus $(\mathrm{Pa})$ & $6.96 \times 10^{10}$ \\
\hline Shear Modulus $(\mathrm{Pa})$ & $2.67 \times 10^{10}$ \\
\hline Coefficient of thermal expansion $\left(10^{-5} /{ }^{\circ} \mathrm{C}\right)$ & 2.3 \\
\hline Reference Temperature $\left({ }^{\circ} \mathrm{C}\right)$ & 22 \\
\hline Specific heat $\left(\mathrm{J} / \mathrm{Kg}^{\circ} \mathrm{C}\right)$ & 875 \\
\hline
\end{tabular}

Tab. 4. Mechanical properties of grey cast iron

\begin{tabular}{ll}
\hline Properties & Conditions \\
\hline Density $\left(\mathrm{kg} / \mathrm{m}^{3}\right)$ & 1750 \\
\hline Poisson's ratio & 0.2 \\
\hline Elastic Modulus $(\mathrm{Pa})$ & $2.30 \times 10^{11}$ \\
\hline Ultimate Tensile strength $(\mathrm{Pa})$ & $3.50 \times 10^{9}$ \\
\hline Bulk modulus $(\mathrm{Pa})$ & $1.28 \times 10^{11}$ \\
\hline Shear Modulus $(\mathrm{Pa})$ & $9.58 \times 10^{10}$ \\
\hline Coefficient of thermal expansion $\left(10^{-6} /{ }^{\circ} \mathrm{C}\right)$ & 2.1 \\
\hline Reference Temperature $\left({ }^{\circ} \mathrm{C}\right)$ & 22 \\
\hline
\end{tabular}

Tab. 5. Mechanical Properties of CF-Epoxy

\begin{tabular}{ll}
\hline Properties & Conditions \\
\hline Density $\left(\mathrm{Kg} / \mathrm{m}^{3}\right)$ & 7200 \\
\hline Poisson's ratio & 0.28 \\
\hline Elastic Modulus $(\mathrm{Pa})$ & $1.10 \times 10^{11}$ \\
\hline Ultimate Tensile strength $(\mathrm{Pa})$ & $2.40 \times 10^{8}$ \\
\hline Bulk modulus $(\mathrm{Pa})$ & $8.33 \times 10^{10}$ \\
\hline Shear Modulus $(\mathrm{Pa})$ & $4.29 \times 10^{10}$ \\
\hline Coefficient of thermal expansion $\left(10^{-5} /{ }^{\circ} \mathrm{C}\right)$ & 1.1 \\
\hline Specific heat $\left(\mathrm{J} / \mathrm{Kg}{ }^{\circ} \mathrm{C}\right)$ & 447 \\
\hline Reference Temperature $\left({ }^{\circ} \mathrm{C}\right)$ & 22 \\
\hline
\end{tabular}

Tab. 6. Mechanical properties of Titanium Alloy

\begin{tabular}{ll}
\hline Properties & Conditions \\
\hline Density $\left(\mathrm{kg} / \mathrm{m}^{3}\right)$ & 4620 \\
\hline Poisson's ratio & 0.3 \\
\hline Elastic Modulus $(\mathrm{Pa})$ & $7.10 \times 10^{10}$ \\
\hline Ultimate Tensile strength $(\mathrm{Pa})$ & $3.10 \times 10^{8}$ \\
\hline Tensile Yield Strength $(\mathrm{Pa})$ & $2.80 \times 10^{8}$ \\
\hline Compressive Yield Strength $(\mathrm{Pa})$ & $2.80 \times 10^{8}$ \\
\hline Bulk modulus $(\mathrm{Pa})$ & $6.96 \times 10^{10}$ \\
\hline Shear Modulus $(\mathrm{Pa})$ & $2.67 \times 10^{10}$ \\
\hline Coefficient of thermal expansion $\left(10^{-6} /{ }^{\circ} \mathrm{C}\right)$ & 9.4 \\
\hline Reference Temperature $\left({ }^{\circ} \mathrm{C}\right)$ & 22 \\
\hline Specific heat $\left(\mathrm{J} / \mathrm{Kg}^{\circ} \mathrm{C}\right)$ & 522 \\
\hline
\end{tabular}

Tab. 7. Mechanical properties of Structural steel

\begin{tabular}{ll}
\hline Properties & Conditions \\
\hline Density $\left(\mathrm{kg} / \mathrm{mm}^{3}\right)$ & $7.85 \times 10^{-6}$ \\
\hline Poisson's ratio & 0.36 \\
\hline Elastic Modulus $(\mathrm{Pa})$ & $9.6 \times 10^{10}$ \\
\hline Ultimate Tensile strength $(\mathrm{Pa})$ & $1.07 \times 10^{9}$ \\
\hline Tensile Yield Strength $(\mathrm{Pa})$ & $9.3 \times 10^{8}$ \\
\hline Compressive Yield Strength $(\mathrm{Pa})$ & $9.3 \times 10^{8}$ \\
\hline Bulk modulus $(\mathrm{MPa})$ & $1.142 \times 10^{11}$ \\
\hline Shear Modulus $(\mathrm{Pa})$ & $3.52 \times 10^{10}$ \\
\hline Coefficient of thermal expansion $\left(10^{-5} /{ }^{\circ} \mathrm{C}\right)$ & 1.2 \\
\hline Reference Temperature $\left({ }^{\circ} \mathrm{C}\right)$ & 22 \\
\hline Specific heat $\left(\mathrm{J} / \mathrm{Kg}{ }^{\circ} \mathrm{C}\right)$ & $4.34 \times 10^{5}$ \\
\hline Thermal conductivity $\left(\mathrm{W} / \mathrm{m}^{\circ} \mathrm{C}\right)$ & 21.9 \\
\hline
\end{tabular}

\section{MODELLING OF FRAME AND ANALYSIS CONDITIONS}

After selection of suitable alternative materials for the chassis frame, modelling of the frame of a two wheeler electrical bike was carried by using Solid Works 2015 software. The software has an inbuit feature of assembling all the components through mate option easily. The exact dimensions of Yamaha R15 consisting of 44 parts are drawn individually and assembled through mate opotion present in the solid works softare. Fig 1 represents the exact dimensions of Yamaha R15 considered for the analysis and Fig. 2 represents solid model after extruding the dimensions. 


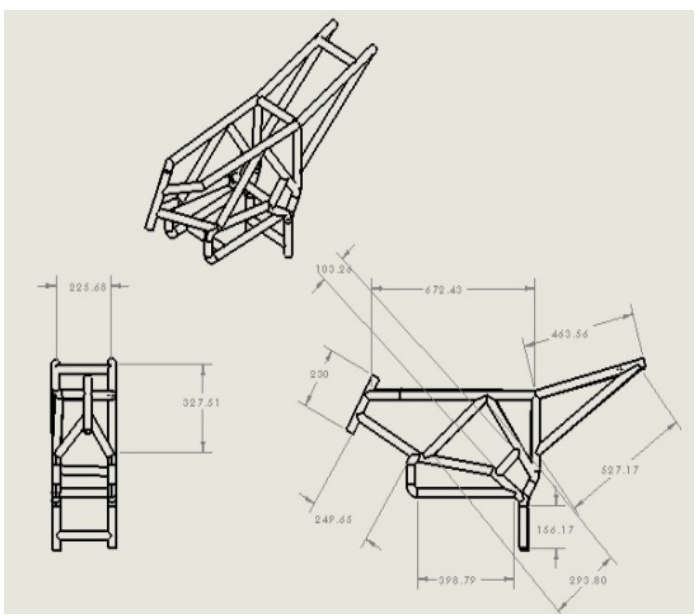

Fig. 1. Exact dimensions of Yamaha R15 frame

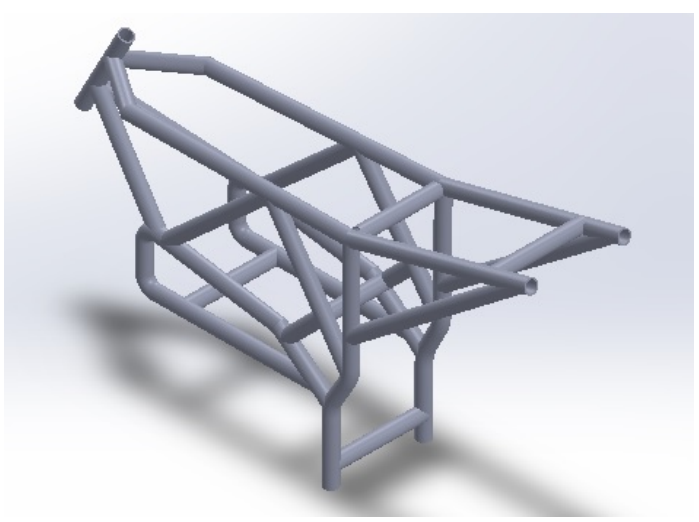

\subsection{Static analysis}

The frame of electrical bike modeled using solid works soft ware was imported to (.igs) format to perform static and impact analysis. Initially static analysis was performed by using static structural tool present in the Ansys work Bench. Static analysis is the primary analysis to be performed for analyzing the behavior of any mechanical components subjected to loading conditions under rest position. Figure 3 represents loads acting on the chasing frame. A total load of $1500 \mathrm{~N}$ is applied on the chassis frame with variation of material properties and the values of von Mises stress and deformation are noted. Table 8 represents the loading and boundary conditions applied on the frame.

Tab. 8. Loading and boundary conditions applied on frame for performing static analysis

\begin{tabular}{ll}
\hline Boundary conditions & Parameters \\
\hline Fixed Position & lower part of the frame \\
\hline $\begin{array}{l}\text { load applied on front } \\
\text { frame }\end{array}$ & $\begin{array}{l}\text { Total 1000 N (500 N each on left } \\
\text { and right frame of front seat) }\end{array}$ \\
\hline Load applied on the & $\begin{array}{l}\text { Total 500 N (200 N each on left } \\
\text { and right frame of back seat and 50 } \\
\text { back frame }\end{array}$ \\
& $\begin{array}{l}\text { N each on middle and back } \\
\text { supports of the frame) }\end{array}$ \\
\hline Materials of frame & AISI1020, Ti-Al, Al-Al, G-CI, \\
& ST-S, CF-E \\
\hline Type of meshing & $\begin{array}{l}\text { Quadrilateral coarse fine mesh } \\
\text { having 54897 nodes and 19782 } \\
\text { elements }\end{array}$ \\
\hline
\end{tabular}

Fig. 2. Solid model of chassis frame

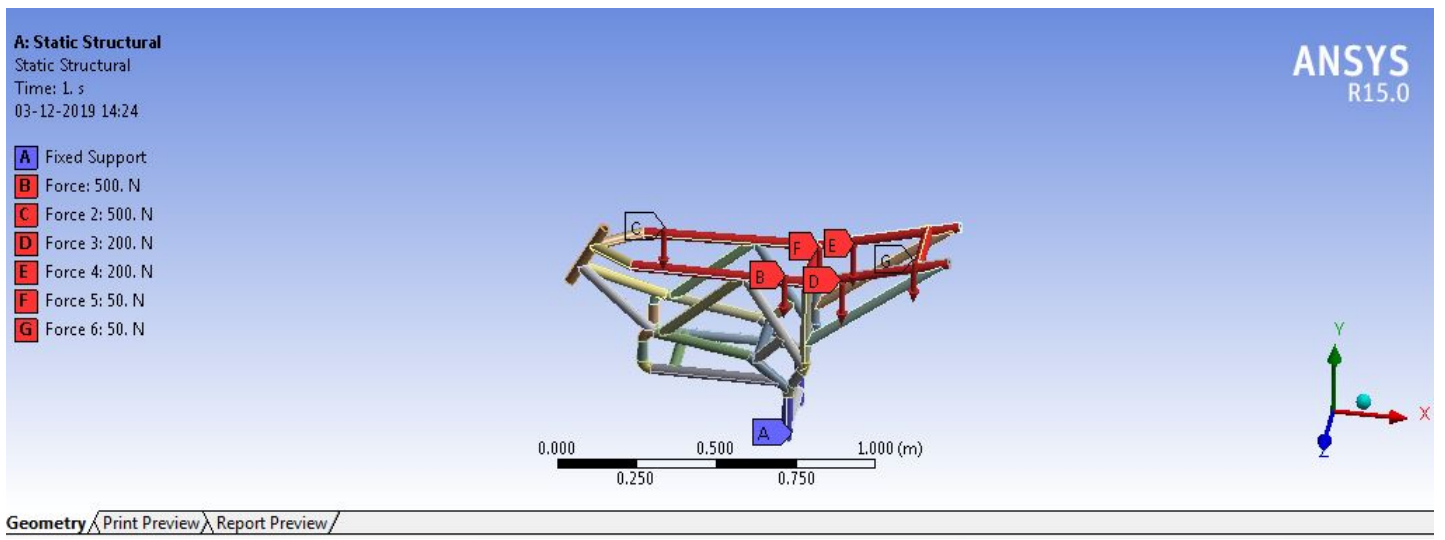

Fig. 3. Loads applied on the chassis frame for static analysis 


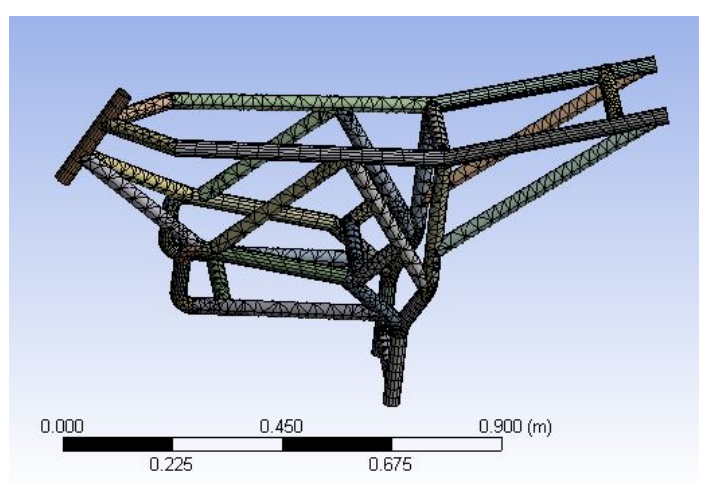

Fig. 4. Chassis frame after meshing

\subsection{Impact analysis}

The failure analysis of an automobile can be completely assessed by performing impact analyis. In this anlysis, the chassis frame of two wheeler vehicle is given an impact velocity along negative $\mathrm{X}$ direction. An obstacle made of strictural steel having dimensions of $(100 \times 100 \mathrm{~mm})$ is placed at a distance of $50 \mathrm{~mm}$ from the front position of the frame. The frame designed for the static analysis is modified to attach an extended rod at the steering position for performing impact analysis. The extented rod is paced at the location of mounting of wheels to the vehicle at the front position. If an impact takes place in the vehicle, the load is initially distributed to the front extented part of the steering frame. Fig 5 represents the meshed model of chassis frame and structural steel bumper for performing impact analysis. Table 9 gives the information of loads and boundary conditions appplied for impact analysis.

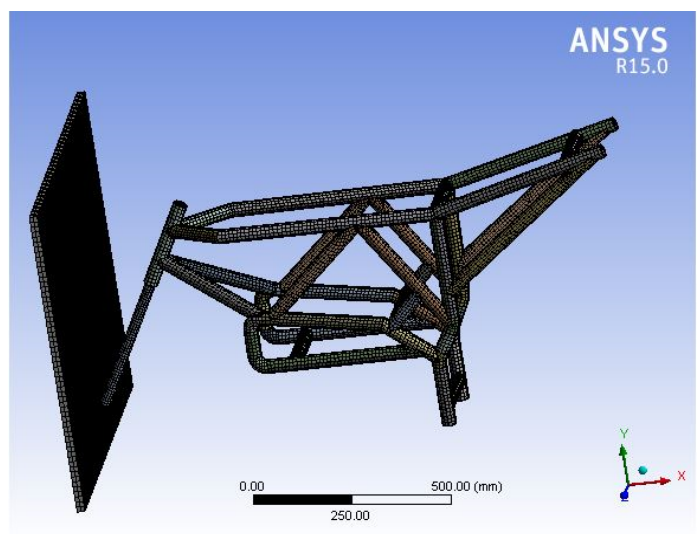

Fig. 5. Meshed model of frame and bumper

The impact analysis was performed on the frame by consisdering an impact velocity of $27.7 \mathrm{~m} / \mathrm{s}$ which is equal to the vehicle moving at higher speed of 100 Kmph. The actual performance of the vehicle at high speed conditions is considered for this study. The frame hit with high impact force on the bumper palced at a distance of $50 \mathrm{~mm}$ from the steering position.
The impact analysis was performed based on few assumptions. The assumptions involved in this study are given below.

Assumptions involved in performing impact analysis:

- the weight of the automobile is neglected in this analysis,

- the modulus of elasticity and deformation of all the parts are neglected,

- inertia forces acting during dynamic movement of the vehicle are neglected,

- traction force between the tire and road conditions are not consisdered in this study,

- structural steel plate at some distance is only considered for impact,

- velocity factor is considred in this study along the direction of impact.

Tab. 9. Loading and boundary condiions for performing impact analysis

\begin{tabular}{ll}
\hline Boundary conditions & Parameters \\
\hline Fixed Position & $\begin{array}{l}\text { Steering mounting frame head is } \\
\text { fixed and displacements along Y } \\
\text { and Z directions are constrained }\end{array}$ \\
\hline Impact velocity & $27.7 \mathrm{~m} / \mathrm{s}$ along X direction (-ve) \\
\hline Materials of frame & $\begin{array}{l}\text { AISI1020, Ti-Al,Al-Al, Grey cast } \\
\text { iron, St-s, CF-E }\end{array}$ \\
\hline & $\begin{array}{l}\text { Quadrilateral coarse fine mesh } \\
\text { having 54897 nodes and 19782 } \\
\text { elements }\end{array}$ \\
\hline
\end{tabular}

\section{RESULTS AND DISCUSSIONS}

Based on static and impact analysis performed on two wheeler chassis frame, the vonmisess stress and deformation values for different materials are observed. After observing the results of one material, the procedure was repeated by change the material properties of the frame. The best material which exhibits higher values of von Mises stress and lower value of deformation is considered for the design and fabrication. The results of static and impact analysis are given below.

Static analysis results reveal that under the action of a total load of $1500 \mathrm{~N}$ acting on the frame, it was observed from the values of graphical representation of von Mises stress and deformation graphs prsented in Fig. 18 and Fig. 19, CF-Epoxy composite material exhibits higher value of von Mises stress $(7.659 \mathrm{E}+7 \mathrm{~Pa})$ and lower value of deformation $\left(0.304 * 10^{-6} \mathrm{~mm}\right)$ compared to remaining materials. The properties of carbon fiber such as high modulus, toughness and high specific strength make the fiber reinforced composite to sustain greater load compared to remaining materials under static conditions. 
4.1. Static analysis Results

\section{AISI 1020 material}

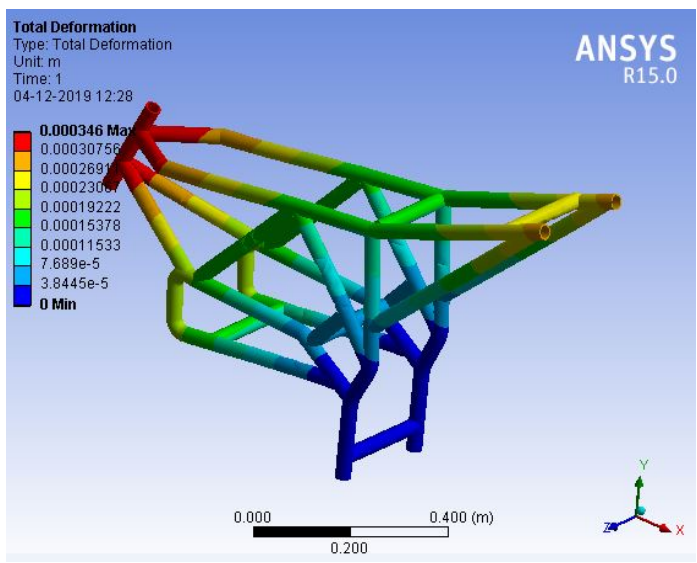

Fig. 6. Total deformation for AISI 1020

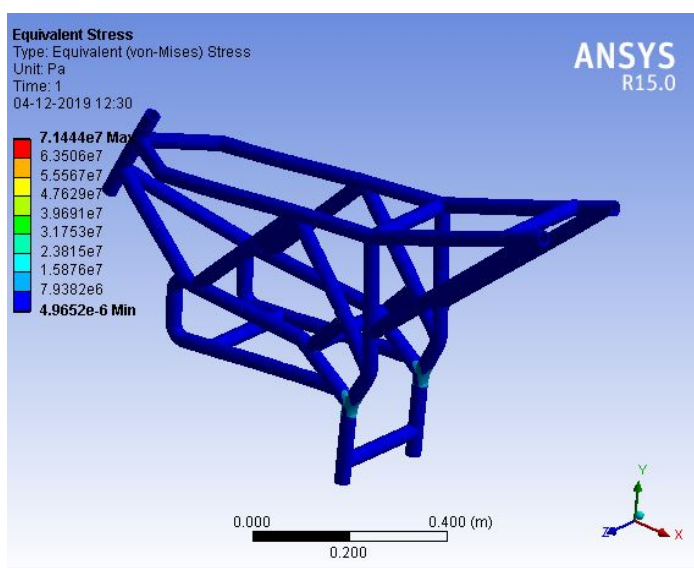

Fig. 7. Equivalent Von Mises stress for AISI1020

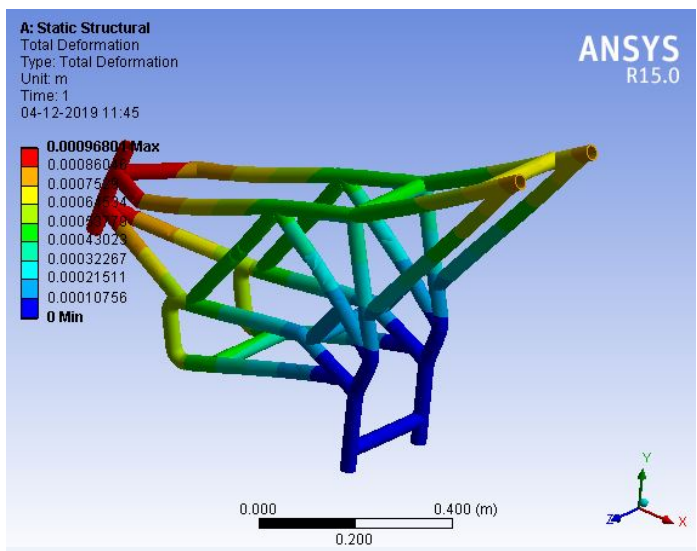

Fig. 8. Total deformation for Al-A

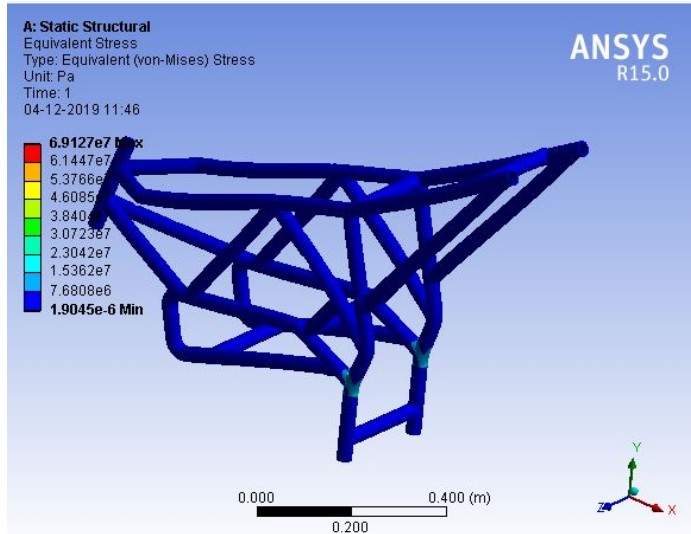

Fig. 9. Equivalent von Mises stress generation for Al-A

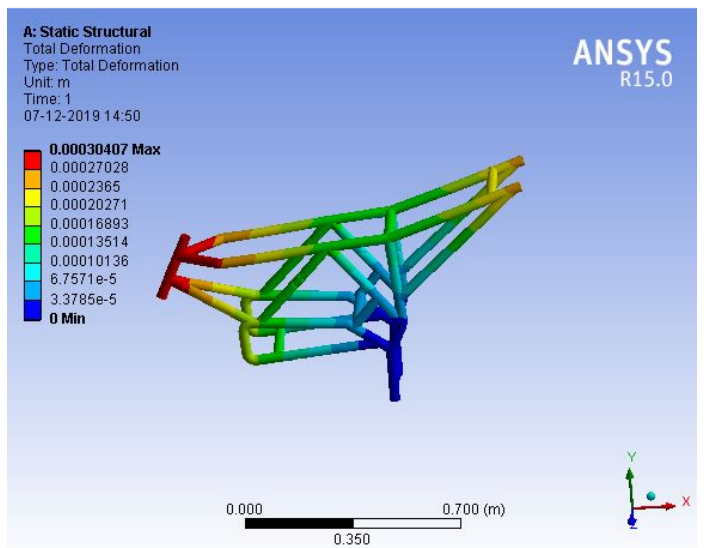

Fig. 10. Total deformation generated for CF-E

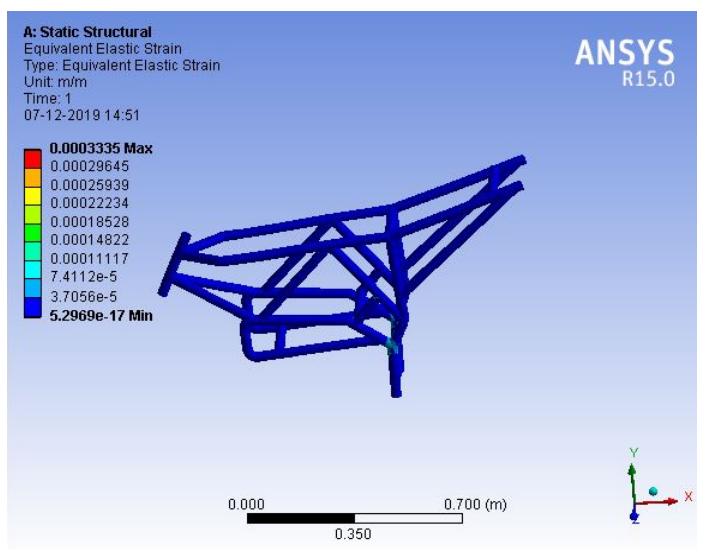

Fig. 11. Equivalent Von Mises generated for CF-E 


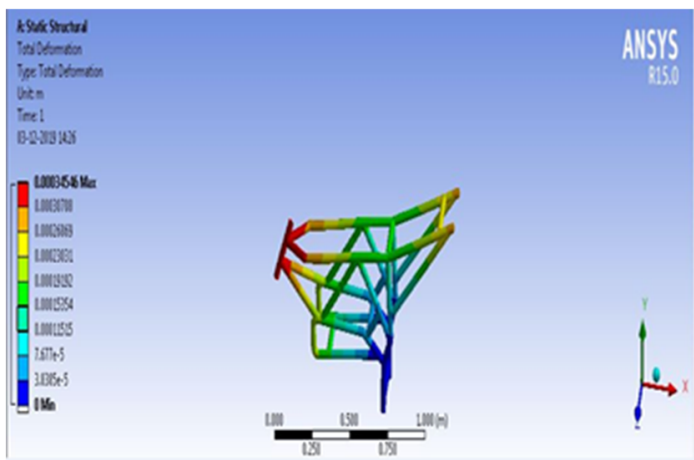

Fig. 12. Total deformation generated for ST-S

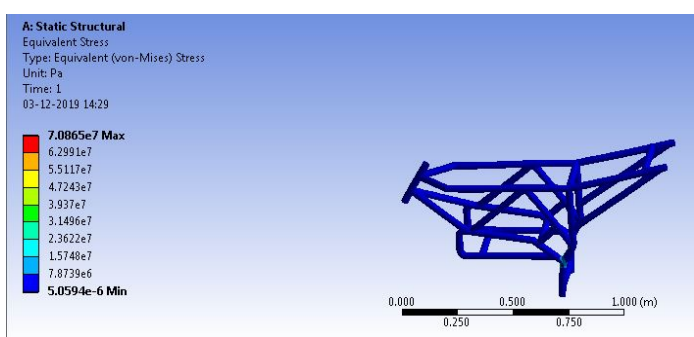

Fig. 13. Equivalent Von Mises stress generated for ST-S

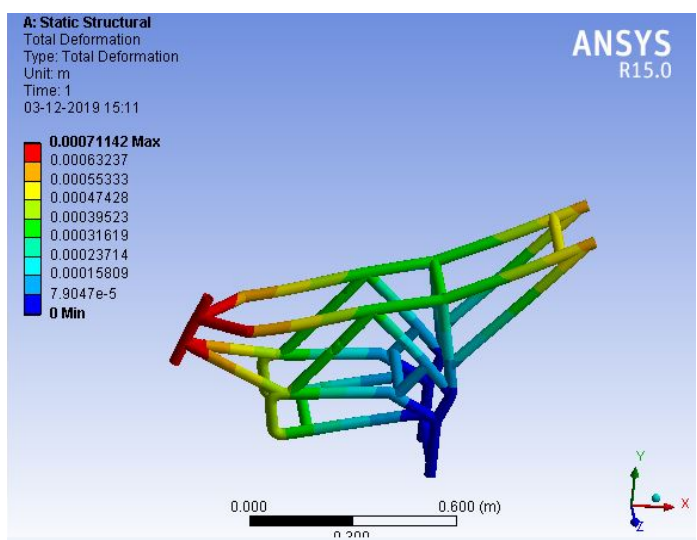

Fig. 14. Total deformation generated for Ti-A

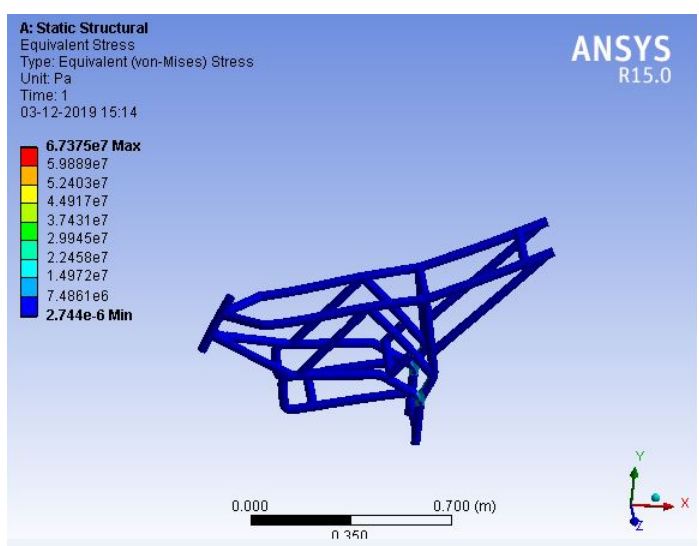

Fig. 15. Equivalent von Mises stress generated for Ti-A

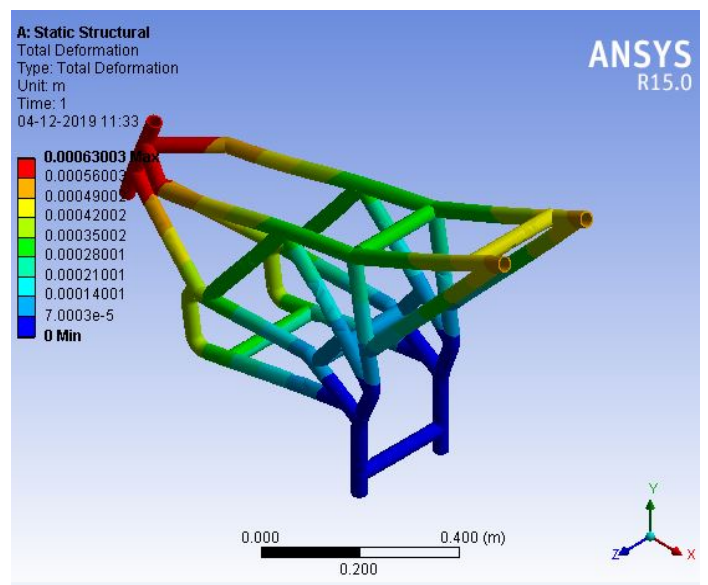

Fig. 16. Total deformation generated for G-CI

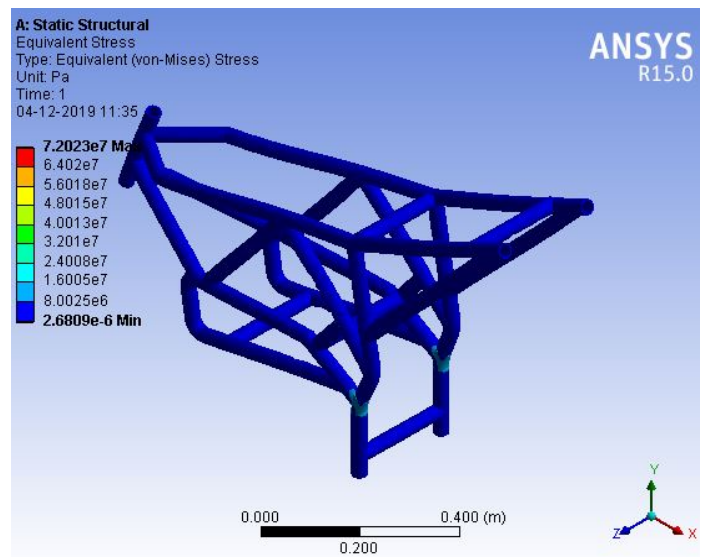

Fig. 17. Equivalent von Mises stress generated for G-CI

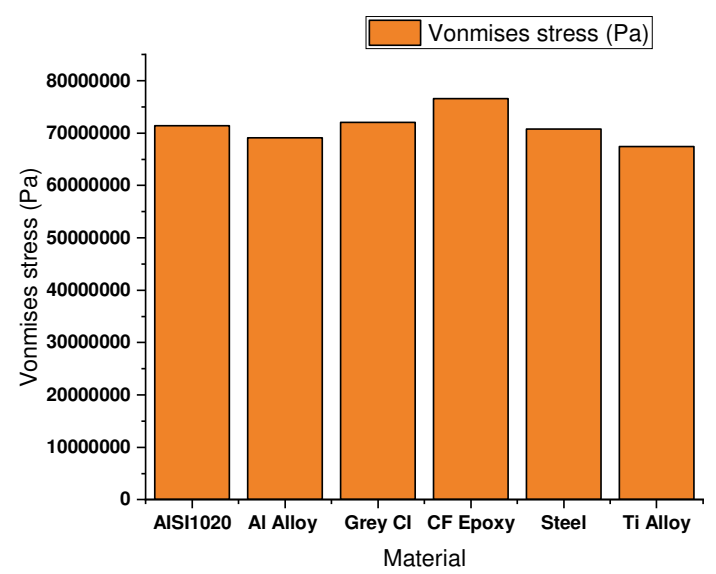

Fig. 18. Graphical representation of Equivalent von Mises stress under static load for different materials 


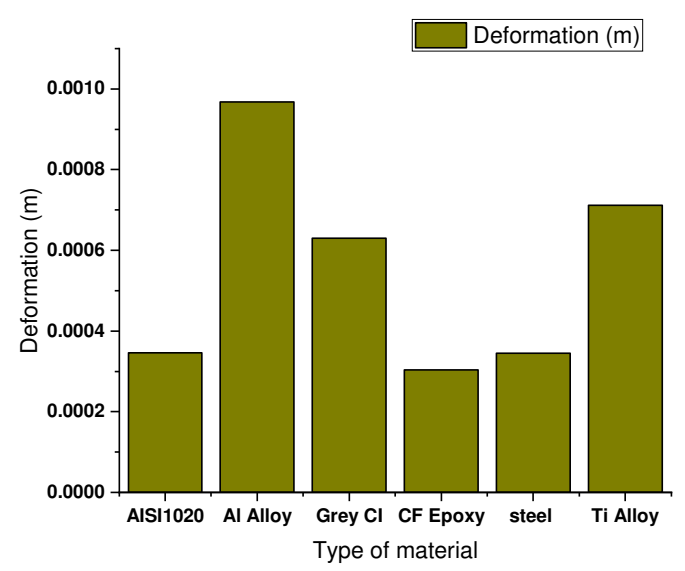

Fig. 19. Graphical representation of total deformation values under static load for different materials

Tab. 10. Values of Equivalent von Mises stress and deformation for all materials under static load

\begin{tabular}{lll}
\hline Material & $\begin{array}{l}\text { Equivalent von } \\
\text { Mises stress }(\mathrm{Pa})\end{array}$ & $\begin{array}{l}\text { Total deformation } \\
(\mathrm{m})\end{array}$ \\
\hline AISI1020 & $7.14 \mathrm{E}+07$ & 0.000346 \\
\hline Al Alloy & $6.91 \mathrm{E}+07$ & 0.000968 \\
\hline Grey cast iron & $7.20 \mathrm{E}+07$ & 0.00063 \\
\hline CF Epoxy & $7.66 \mathrm{E}+07$ & 0.000304 \\
\hline Steel & $7.08 \mathrm{E}+07$ & 0.000345 \\
\hline Ti Alloy & $6.74 \mathrm{E}+07$ & 0.000711 \\
\hline
\end{tabular}

\subsection{Impact analysis Results}

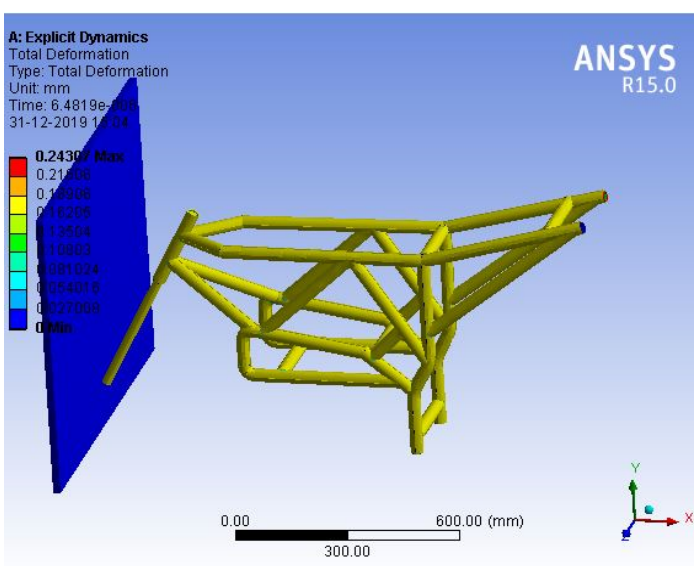

Fig. 20. Total deformation for AISI 1020

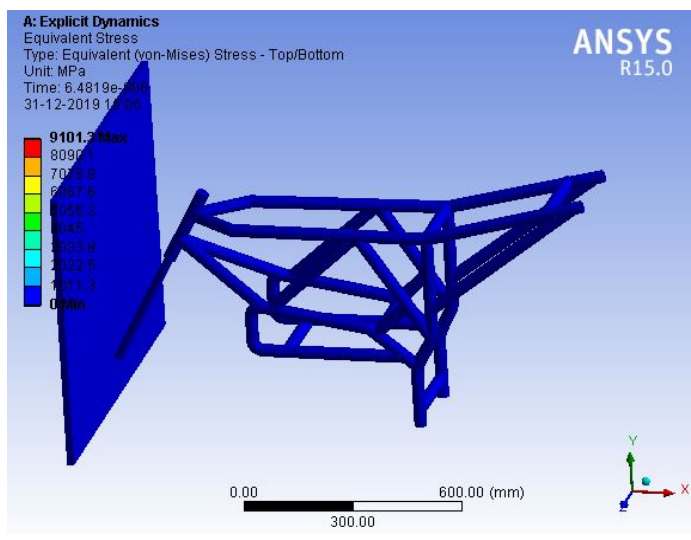

Fig. 21. Equivalent von Mises stress for AISI1020

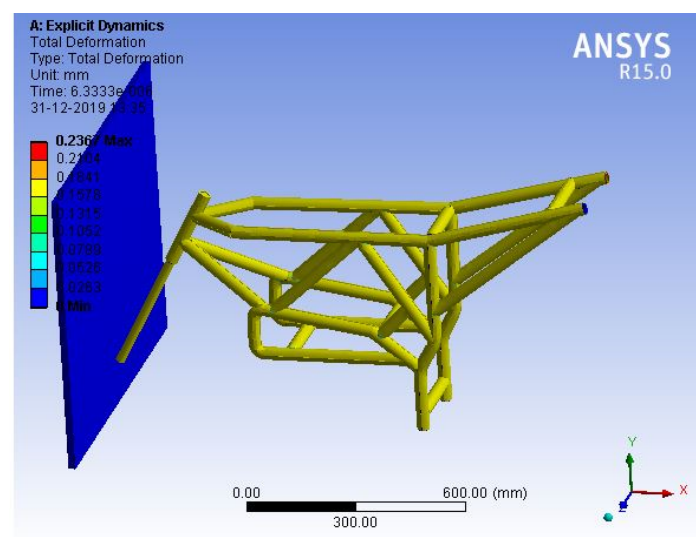

Fig. 22. Total deformation for Al-A

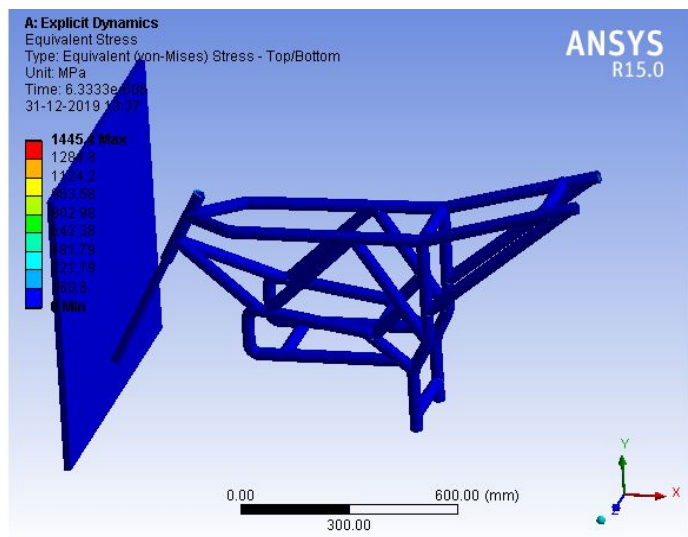

Fig. 23. Equivalent Von Mises stress generation for Al-A 


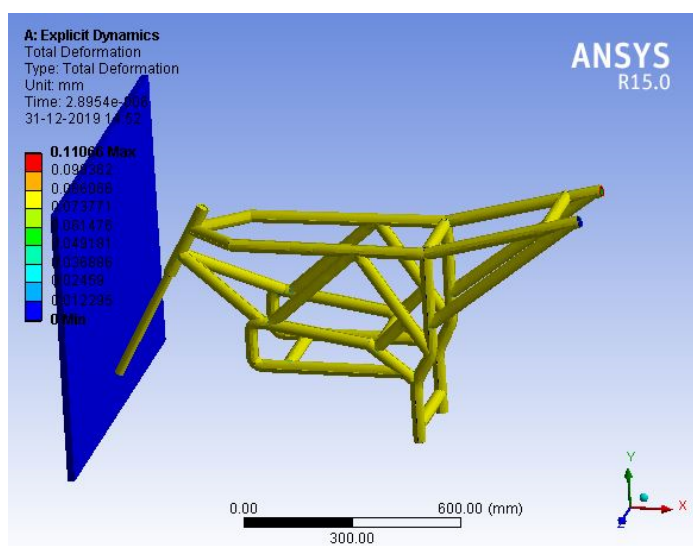

Fig. 24. Total deformation for CF-E

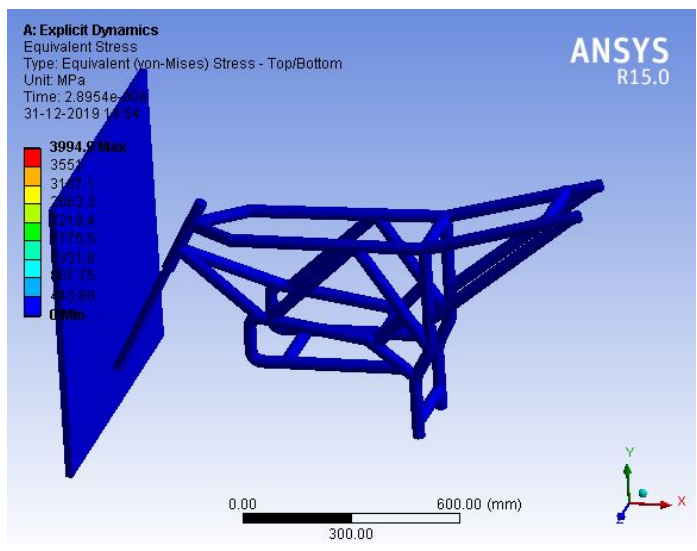

Fig. 25. Equivalent von Mises stress generation for CF-E

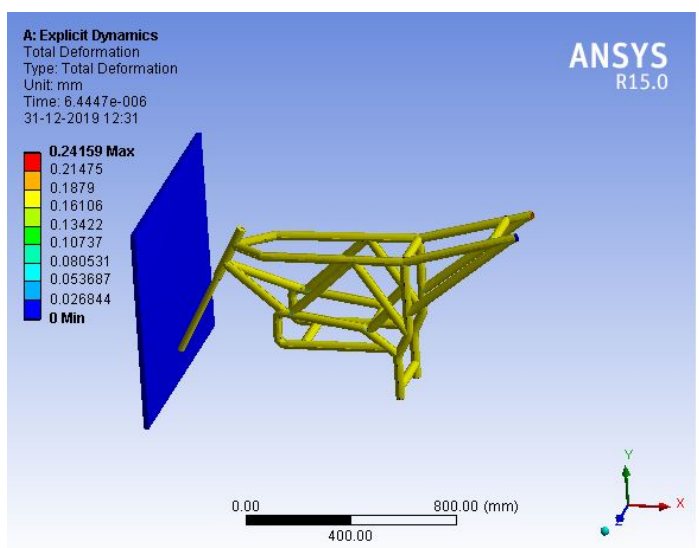

Fig. 26. Total deformation for ST-S

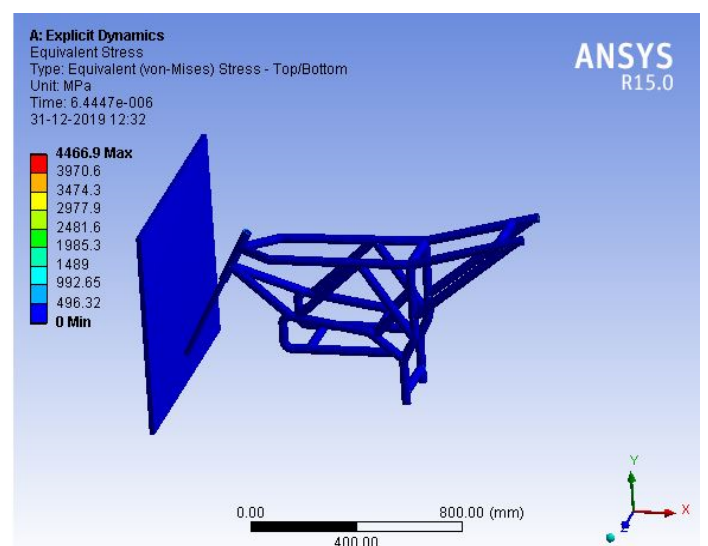

Fig. 27. Equivalent von Mises stress generation for ST-S

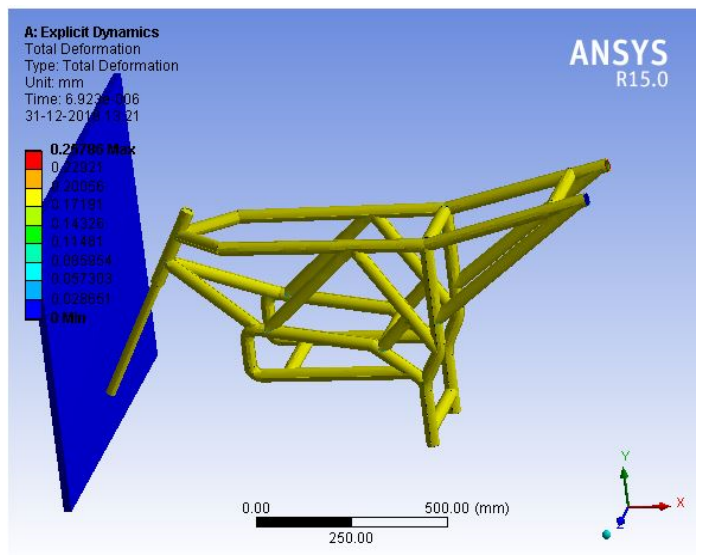

Fig. 28. Total deformation for Ti-A

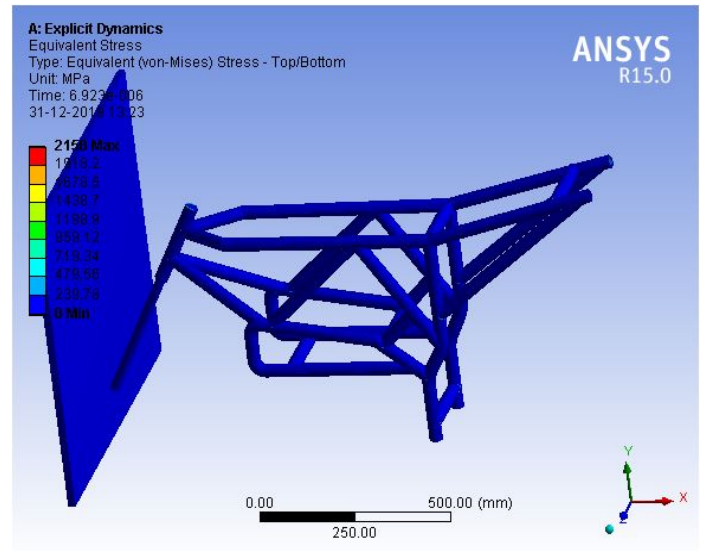

Fig. 29. Equivalent Von Mises stress generation for Ti-A 


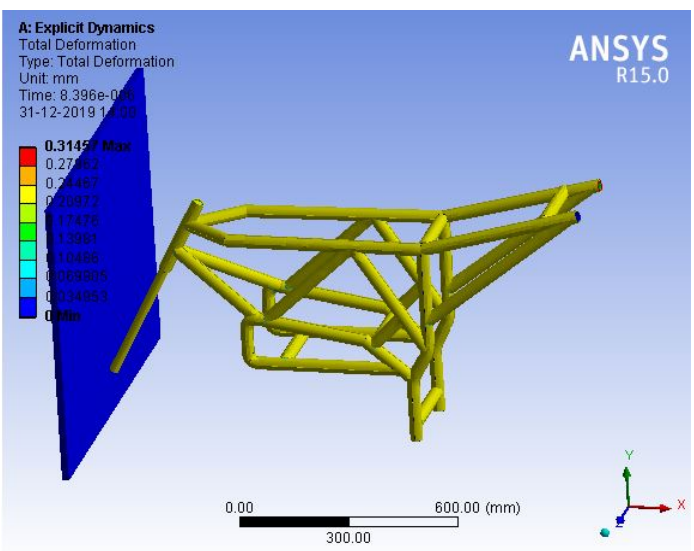

Fig. 30. Total deformation for G-CI

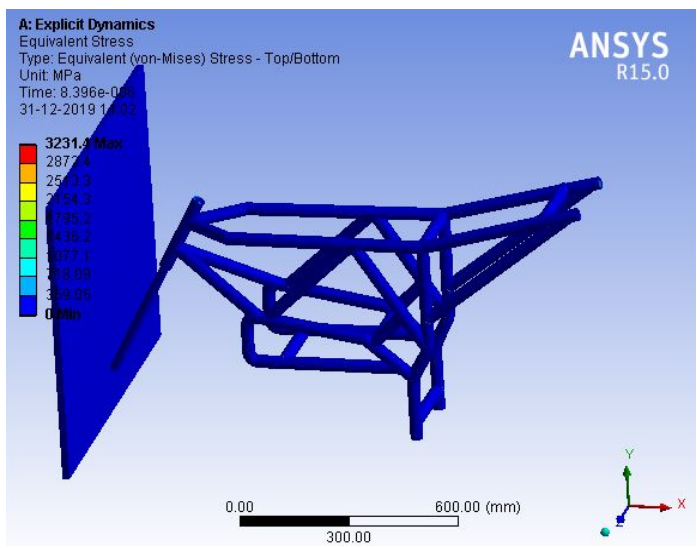

Fig. 31. Equivalent von Mises stress generation for G-CI

Tab. 11. Values of Equivalent von Mises stress and total deformation under impact load

\begin{tabular}{lll}
\hline Material & $\begin{array}{l}\text { Equivalent von } \\
\text { Mises stress }(\mathrm{MPa})\end{array}$ & $\begin{array}{l}\text { Total deformation } \\
(\mathrm{mm})\end{array}$ \\
\hline AISI1020 & $9.10 \mathrm{E}+03$ & 0.243 \\
\hline Al Alloy & $1.45 \mathrm{E}+03$ & 0.2367 \\
\hline Grey cast iron & 3231.4 & 0.3145 \\
\hline CF Epoxy & 3994.9 & 0.1106 \\
\hline Structural Steel & $4.47 \mathrm{E}+03$ & 0.24159 \\
\hline Ti Alloy & $2.16 \mathrm{E}+03$ & 0.25786 \\
\hline
\end{tabular}

Fig. 32 and Fig. 33 represent the graphical representation of values of von Mises stress and deformation observed on a frame under high impact velocity. Based on the results, it was observed that AISI 1020 material possess higher value of Equivalent von Mises stress $(9.10 * 103 \mathrm{MPa})$ compared to remaining materials. The total deformation value for CF-Epoxy was observed to be very less $(0.1106 \mathrm{~mm})$ compared to remaining materials. The value of von Mises stress for CF-Epoxy was also observed to be (3994.9 MPa) closer to that of AISI1020 and structural steel metals. Hence CF-Epoxy can also have the possibility to act as substitute materials to metals like AISI1020 and steels to sustain impact loads acting on the frame.

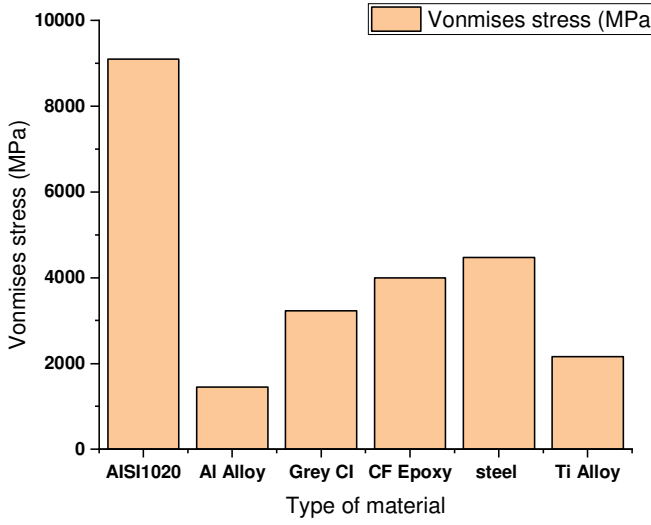

Fig. 32. Graphical representation of Equivalent von Mises stress under static load for different materials

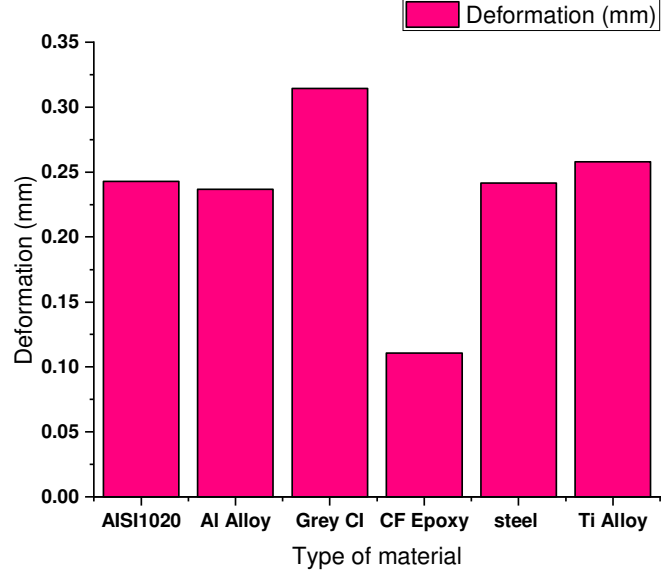

Fig. 33. Graphical representation of total deformation under static load for different materials

\section{CONCLUSION}

Static and impact analysis was performed on the chassis frame of Yamaha R15 E-bike before fabrication. The following conclusions are drawn from this study:

1. After performing static analysis on chassis frame by applying a load of $1500 \mathrm{~N}$ and varying the materials properties of the bike, it was observed that CF-Epoxy composite material exhibited better lower value of total deformation $\left(0.304 * 10^{-6} \mathrm{~mm}\right)$ and higher value of equivalent von Mises stress of $(7.659 * 107 \mathrm{~Pa})$ compared to remaining materials. The total deformation for CF-E is $13.3 \%$ lesser than existing AISI 1020 material. The value of von Mises stress for CF-E is observed to be $51.4 \%$ greater than existing AISI 1020 material.

2. After performing impact analysis on chassis frame by applying impact velocity of $27.7 \mathrm{~m} / \mathrm{s}$ along negative $\mathrm{X}$ direction of the frame, it was observed that CF-Epoxy composite material exhibited better lower value total deformation of $(0.1106 \mathrm{~mm})$ and the value of von Mises stress for CF-Epoxy is also 
observed to be (3994.9 MPa) closer to AISI1020 and structural steel materials . The deformation for $\mathrm{CF}-\mathrm{E}$ is $13.24 \%$ lesser than existing AISI 1020 material.

Hence based on these observations, CF-Epoxy composite materials are having greater chance to replace AISI1020 and structural steel materials. CF-E composite material with proper fabrication methodology can replace the metals used in E Bike technology and produce higher stiffness to weight ratio, lower deformation and with stand higher loads closer to metals.

\section{Acknowledgements}

The authors would like to thank Anits Engineering College for providing the laboratory facilities to use Solid works and Ansys software's for performing this analysis.

\section{References}

1. Y. Champoux, P. Vittecoq "Measuring the dynamic structural load of an off road bicycle frame" Experimental Techniques Vol-28 (2004) PP 33-36

2. Michael Kaiser, Norbert Himmel "Carbon Fiber Reinforced Plastics - Trendsetting Material for High Performance Racing Bike Chassis" The Engineering Of Sport 6 (2005) PP 123-128

3. Vignesh.M, Dr. Arumugam K, Vinoth.S, Hariharan.S "Design and Analysis of Frame of an Electric Bike" International Journal of Engineering Science Invention (IJESI) Vol-8 (2019) PP 08-16

4. Maulik Lohia, Prof. Mohsin Bukhari, Prof.Dhaval P Patel, "Stress and Rigidity Analysis of Bike Chassis" JETIR (Journal of Emerging Technologies and Innovative Research), Volume 4, Issue 05 (2017) PP 206-215

5. Sergio Corbera Caraballo, Roberto Alvarez Fernandez et al "A performance based design framework for enhancing decision making at the conceptual phase of a motorcycle rear suspension development" Optimization and Engineering (2019)

6. Balaguru S, Elango Natarajan, Ramesh $\mathrm{S}$ et al, "Structural and modal Analysis of Scooter Frame for Design Improvement" Vol-16, Part- 2(2019) PP 11061116

7. Kiran L et al. Proposal of hybrid composite material for light commercial vehicle chassis. Materials today proceedings, vol5 , 2018, pp 24258-24267

8. Jeyapandiarajan P et al . Design and analysis of chassis for an electric motor cycle., Materials today proceedings, vol5 , 2018, pp 13563-13573

9. Balaguru $\mathrm{S}$ et al . Structural and modal analysis of scooter frame for design improvement. Materials today proceedings, vol6, 2019, pp 1106-1116

\section{Biographical notes}

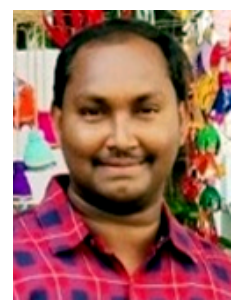

Naresh Kumar Konada is working as an Assistant professor in the department of mechanical engineering, Anits, Visakhapatnam, India. He is in the field of teaching and research since 2010. He published 20 international journals in various fields. $\mathrm{He}$ is currently pursuing $\mathrm{PhD}$ in the department of mechanical engineering, Andhra University. His area of interests includes machine design, nano composites, vibrations and vehicle dynamics.

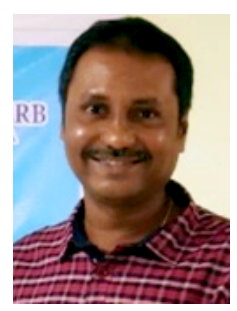

Koka Naga Sai Suman is working as an Associate professor in the department of mechanical engineering, Andhra University, Visakhapatnam, India. He received his doctorate in the year 2006 from Andhra University, in the field of research on under water vehicles in collaboration with naval science and Technological laboratory (NSTL). He received best thesis award during that year by Andhra University. He received senior research fellowships from UGC and CSIR. His area of research interests includes mechanical behavior of composites, nano materials and manufacturing. 
